\title{
研究速報
}

\section{D コンテンツの視差量の分析}

A Method for Analyzing the Image Disparity of 3D Video

\author{
正会員 中 村 芳 知 $^{\dagger 1}$, 工藤広太郎 ${ }^{\dagger 2}$, \\ 竹 本 雅 憲 ${ }^{\dagger}$, \\ 正会員窪田＼cjkstart悟 ${ }^{\dagger 2}$, 嶋田淳 ${ }^{\dagger 3}$ \\ Yoshitomo Nakamura ${ }^{\dagger 1}$, Koutaro Kudo ${ }^{\dagger 2}$, Masanori Takemoto ${ }^{\dagger 2}$, \\ Satoru Kubota ${ }^{\dagger 2}$ and Atsushi Shimada ${ }^{\dagger 3}$
}

\begin{abstract}
A method is described for analyzing the image disparity of 3D video. This method was used to analyze the image disparity characteristics of forty 3D movies. The percentage of image disparities that were outof-range by one degree or more was higher in the convergent direction than in the divergent direction. Characteristics of the image disparity for 3D video are discussed in relation to the results.
\end{abstract}

キーワード：3Dテレビ，視覚疲労，立体映像，両眼視差，ステレオマッチング，視差量

\section{1.まえがき}

近年，両眼視差を利用した立体映像，いわゆる3D映像コ ンテンツを一般家庭でもテレビで視聴できる環境が整って きた. 3DコンテンツはBlu-ray Discとして市販されている ほか, 放送業界ではBS, CS, ケーブル局の有料放送事業 者を中心に一部の局で放送が開始されている.

一方，3Dコンテンツの普及には，視覚疲労の軽減が一つ の課題とされている. 3D コンテンツの視聴における視覚疲 労は, 調節と輻輳の不一致という原理的な問題が主因であ る $^{1)}$ ５).このことから, 我が国の3Dコンソーシアムの安 全ガイドライン 6) では, 3D 映像における飛出と引达の視差 範囲は，最も飛出ている部分または最も引込でいる部分と， 表示面との輻輳角の差を視差角とした場合, $1^{\circ}$ 以内が快適 に視聴できる範囲としている。

しかし, 市販されている3Dコンテンツの視差角を分析し た例は少なく，さまざまなジャンルの3Dコンテンツにお いて，視差角がどのような分布を成しているかは明らかに されていない，筆者ら ${ }^{7)}$ は，視差角がほぼ $1^{\circ}$ 以内に制限さ

本研究の一部は, 2013 年1月 25 日の情報デイスプレイ研究会で発表した。 2013 年 4 月 4 日受付, 2013 年 7 月 15 日再受付, 2013 年 8 月 30 日採録

$\dagger 1$ 三菱電機株式会社 先端技術総合研究所

（广 661-8661 兵庫県尼崎市塚本町 8-1-1，TEL 06-6497-7595)

$\dagger 2$ 成蹊大学 理工学部

( ₹ 180-8633 武藏野市吉祥寺北町 3-3-1, TEL 0422-37-3720)

$\dagger 3$ 三菱電機株式会社 デザイン研究所

（预 247-8501 鎌倉市大船5-1-1，TEL 0467-41-2310)

$\dagger 1$ Advanced Technology R\&D Center, Mitsubishi Electric Corporation (8-1-1, Tsukaguchi-Honmachi, Amagasaki, Hyogo 661-8661, Japan)

$\dagger 2$ Faculty of Science and Technology, Seikei University (3-3-1, Kichijoji-kitamachi, Musashino-shi, Tokyo 180-8633, Japan)

$\dagger 3$ Industrial Design Center, Mitsubishi Electric Corporation (5-1-1 Ofuna, Kamakura-shi, Kanagawa, 247-8501. Japan)
れた映像でも比較的強い視覚疲労を訴える視聴者もおり， 視覚瘏労の強さは視聴者の眼調節時間を主として，両眼視 力差, 水平斜位などの視機能に依存していることを示した. ただし, 実際の3Dコンテンツの視差の特徵と視覚疲労と の関係は明確にされていない。そこで，まず，一般的に視 聴できる3D コンテンツがどのような視差の特徵を備えて いるかについて測定分析する必要がある.

本研究では，ステレオマッチングによりフレームごとに 画素単位で算出した水平方向の視差のヒストグラムのパー センタイルから, 当該フレームの飛出と引込の視差を求め る方法を提案した。そして，さまざまなジャンルから集め た 40 種類の $3 \mathrm{D}$ コンテンを提案した方法で分析し, 各コ ンテンッの視差の特徴について考察した。

\section{2. 視差量の分析方法}

\section{1 画素ごとの視差量の計測}

3D コンテンツの視差量の測定には，リーダー電子社製の 3DアシストスタジオFS3090を用いた。このシステムは, 主として $3 \mathrm{D}$ コンテンツの制作時に視差を確認するための システムである。本研究では，このシステムをカス夕マイ ズし，画素ごとの視差量をフレーム単位で保存できるよう にした。

このシステムでは，3D映像の再生機からフレームパッキ ング (右眼映像，左眼映像それぞれ $1920 \times 1080$ 画素) で出 力される映像に対して，480×270画素にリサイズした後， ブロックマッチング ${ }^{8)}$ により，一方を基準とした水平方向 の画素視差を算出する。この処理を 1 秒あたり約 6 フレー ムの頻度で行い，フレームごとにすべての画素の視差量を 求めることができる，視差量の測定精度としては，映像を 
リサイズして処理しているため，4画素単位の処理による 誤差が生じ得る。

表 1 に本研究で分析した 40 種類の 3D コンテンツのタイ トルを示した。

\section{2 飛出量と引込量の目視計測}

表1の40コンテンツのうち，アスタリスクを付した8コ ンテンツについては, サンプリングしたフレームの視差量 を目視で計測した。これら8コンテンツは，ジャンルに偏 りがないように選択した。

まず，選択した3D コンテンツを Full-HDの 50 型 3D プラ ズマテレビに表示し，2名の観察者により飛出と引込が比 較的大きいと認識されたシーンを飛出側と引込側でそれぞ れ30フレームずつ抽出した。そして, 抽出したフレームの 飛出と引込の視差を目視で計測した. すなわち, 飛出が大 きいとして抽出したフレームでは, フレームの中で最も飛 出して見える部分の水平方向の視差をメジャーを用いて $m m$ 単位で測定した. 引达が大きいとして抽出したフレー ムでも同様に測定した.メジャーによる $\mathrm{mm}$ 単位の計測精 度については, 1 ピクセルが約 $0.6 \mathrm{~mm}$ で比較的大きいこと

表1 視差分析を行った 40 種類の3D コンテンツ The 40 3D movies used in the disparity analysis.

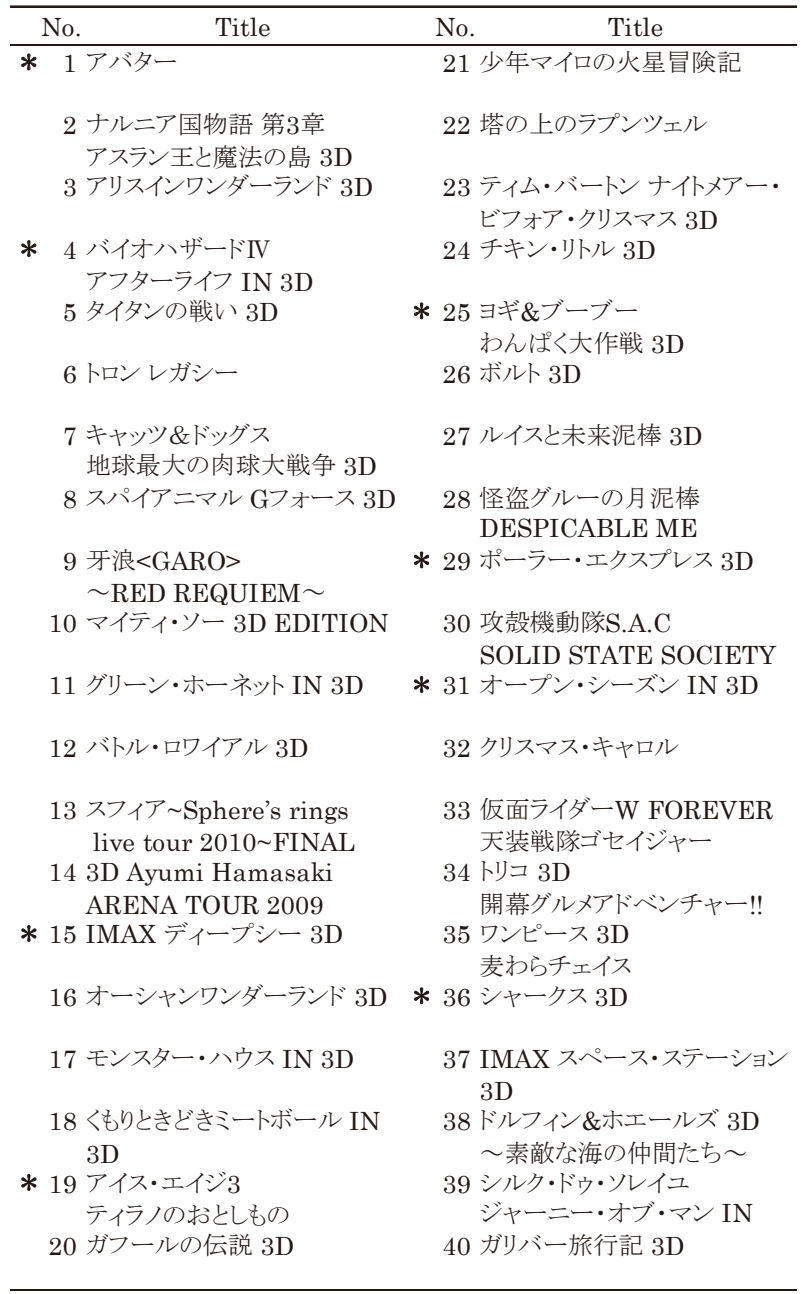

* Disparity of these eight movies was visually measured
と，画像処理による視差分析システムの分析単位が 4 画素 であったため，目視と画像処理結果との相関をとるという 目的では充分であると考えられる.

\section{3 画素ごとの視差量のヒストグラムからの飛出量と引 込量の予測}

ステレオマッチングにより求めた画素ごとの水平視差量 のヒストグラムから, 当該フレームの飛出と引込の視差を 予測する方法について検討した. 図 1 は先に述べた視差分 析システムにより画素ごとの視差量の1フレーム分のヒス トグラムである。「No.1アバター」のある 1 フレームの分析 結果である．このようなヒストグラムのパーセンタイルか ら視聴者が当該フレームで最も飛出ているとする部分と最 も引込んでいるとする部分の視差量を予測できるか検討し た。すなわち，目視計測による飛出および引达の視差と， 図1に示したような視差ヒストグラムのパーセンタイルと の相関を求めた。

図2は，図1のヒストグラムの累積ヒストグラムであり， 2.5 パーセンタイルと 97.5 パーセンタイルをそれぞれ引达視 差と飛出視差と仮定した場合を例示した。目視計測との相

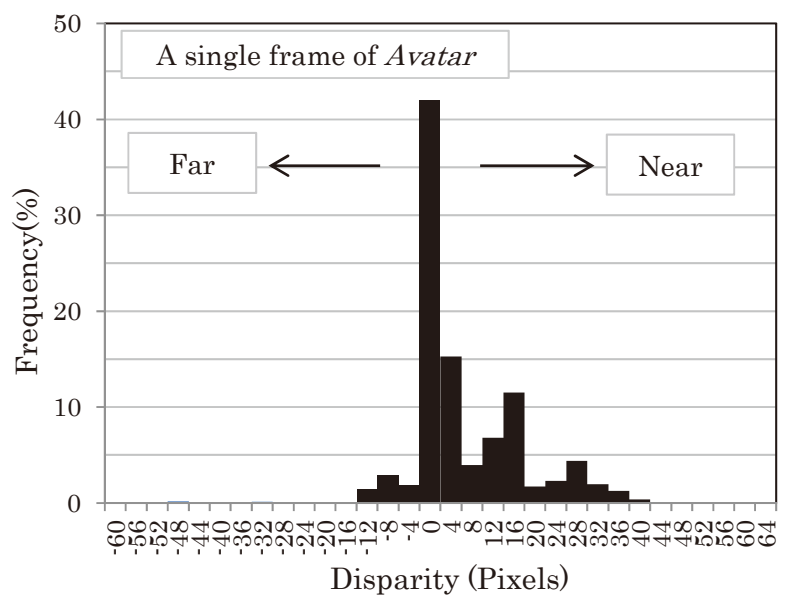

図1 画素ごとの視差量から求めた1フレームの視差ヒストグラムの例 Disparity histogram calculated from single pixel disparities of a single frame.

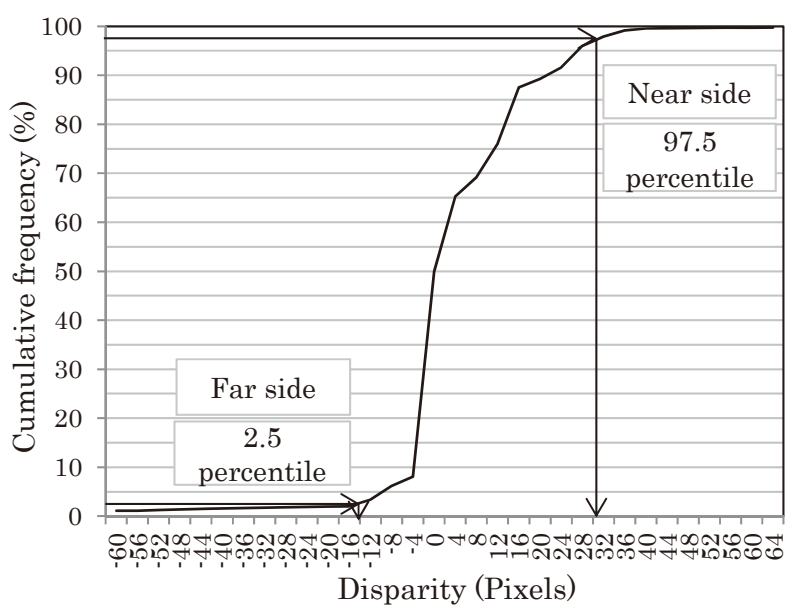

図2 図1の累積ヒストグラム，2.5パーセンタイルと 97.5 パーセンタ イルを例示

Cumulative histogram of Fig. 1 showing the 2.5-97.5 percentiles. 


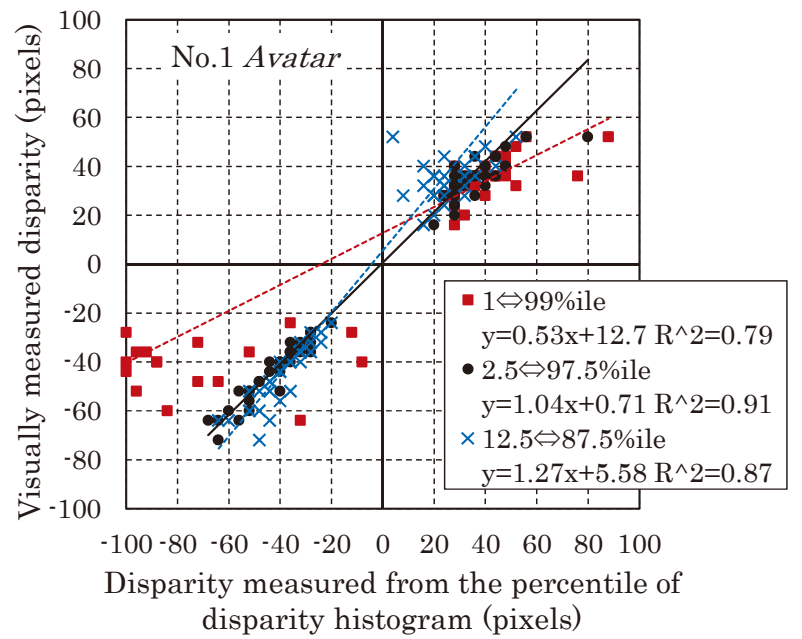

図3 画素ごとの視差量から求めた視差ヒストグラムのパーセンタイ ルと目視による視差計測值との関係

Relationship between the percentile of the disparity histogram and the visual measurement of disparity.

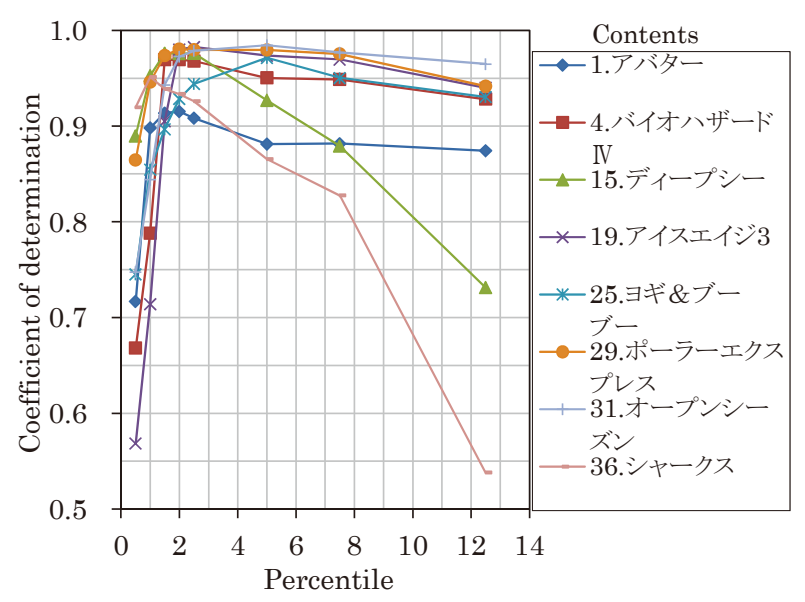

図4 画素ごとの視差量から求めた視差ヒストグラムのパーセンタイ ルと目視による視差計測值との関係を示す単回帰式の寄与率 Coefficient of determination of the linear regression model between the percentile of the disparity histogram and the visual measurement of disparity.

関分析にあたっては，0.5，1，1.5，2，2.5，5，7.5，12.5 パーセンタイルを引达側に適用し，その逆側の 99.5，99, 98.5，98，97.5，95，92.5，87.5パーセンタイルを飛出側に 適用した。図3はこのようにして求めたパーセンタイルを $\mathrm{x}$ 軸, 目視計測した飛出視差と引込視差を $\mathrm{y}$ 軸としてプ ロットした図である。いずれも画面上の視差を Full-HD (1920×1080 画素) で表示した時の画素数で表している. 図3では $1-99,2.5-97.5 ， 12.5-87.5$ の3対のパーセン夕 イルと, 目視計測した飛出と引込の視差との関係のみ示し ている.

目視計測した8つの映像について，図3のようにパーセ ンタイルごとに単回帰式の寄与率を求めた結果を図4に示 す. 最も寄与率が高いのは, $1.5 〜 2.5$ (98.5〜 97.5) パーセ ンタイルで, いずれの映像でも寄与率が 0.9 を超える. 同 様に，8対のパーセンタイルにおける単回帰式の回帰係数

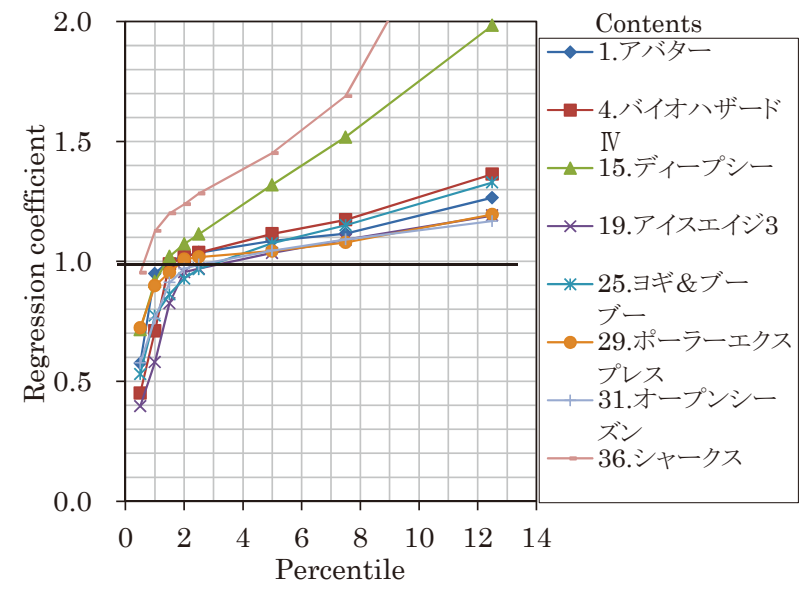

図5 視差量のヒストグラムのパーセンタイルと目視による視差計測 值との関係を示す単回帰式の回帰係数

Regression coefficient between the percentile of the disparity histogram and the visual measurement of disparity.

を図5に示した．回帰係数が1に近いのは1.5〜2.5（98.5〜 97.5) パーセンタイルである. また，定数項がほぼ0になる のも $1.5 \sim 2.5$ (98.5 97.5) パーセンタイルであった. そこ で, この条件の中で $8 つ の$ 映像の寄与率の平均が 0.96 と最 も高かった2.5 (97.5) パーセンタイルの対, すなわち引込側 2.5 パーセンタイルを当該フレームの引込視差, 飛出側 97.5 パーセンタイルを飛出視差とみなして, 40 種類の $3 \mathrm{D}$ コン テンツを分析した。

\section{3. 結果と考察}

図6は，この方法によって1秒あたり約 6 フレームの頻度 で飛出と引込の視差を求め, 当該コンテンッの全体につい

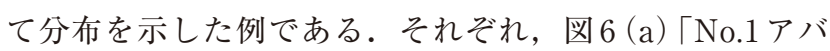
ター」, 図6 (b)「No.12バトルロワイアル」, 図6 (c)「No.15 ディープシー」の飛出, 引达の視差ヒストグラムを示す. 視距離 $3 \mathrm{H}$ (画面高の3 倍) で視聴した場合の視差角 $1^{\circ}$ (FullHD 57 画素の視差に相当)の範囲を図中に示した。先に 述べたように視差角 $1^{\circ}$ は， $3 \mathrm{D}$ コンソーシアムのガイドラ インでも快適視差範囲としている視差角の範囲である.

測定した 40 コンテンッすべてについて同様の処理を施 し, 視差角 $1^{\circ}$ より大きな飛出㧍よび引込があるフレームの 割合を求めてプロットしたのが図7である。すなわち, 視 距離 $3 \mathrm{H}$ での視聴を想定した場合, 視差角 $1^{\circ}$ 以上の飛出が あるフレームの割合を $\mathrm{x}$ 軸，視差角 $1^{\circ}$ 以上の引込があるフ レームの割合を $\mathrm{y}$ 軸として，40コンテンツを散布図として プロットした．分析した 40 コンテンッは，すべて視差角 $1^{\circ}$ を超えるフレームが存在した。視差角 $1^{\circ}$ を超えるフ レームの割合が, 引込側の方が多いコンテンッは 40 コンテ ンツ中 4 コンテンツのみで, 9割は飛出側の方が多かった. 引込側が特に多かったコンテンッは水中のシーンが多い 「No.15ディープシー」と「No.16オーシャンワンダーランド」 であった。逆に $1^{\circ}$ 以上の飛出が多かったのは, 「No.12バ卜 ルロワイアル」と「No.33仮面ライダーW」で，いずれも 
Disparity angle (deg) when viewing at $3 \mathrm{H}$

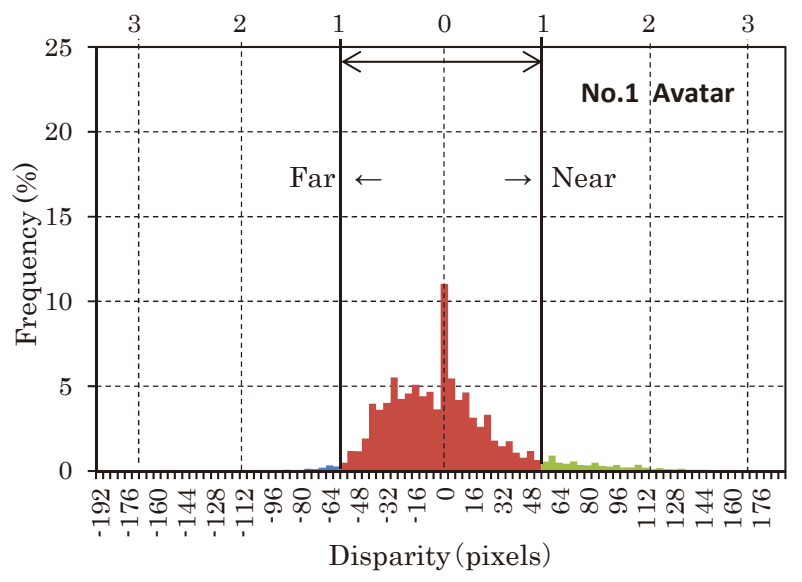

(a) No.1 アバター $[$ Avatar $]$

Disparity angle (deg) when viewing at $3 \mathrm{H}$

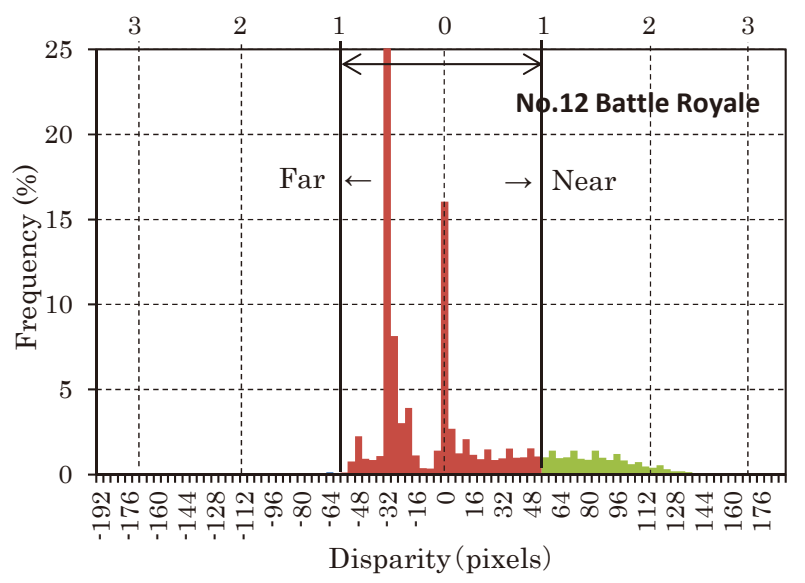

(b) No.12 バトルロワイアル [Battle Royale $]$

Disparity angle (deg) when viewing at $3 \mathrm{H}$

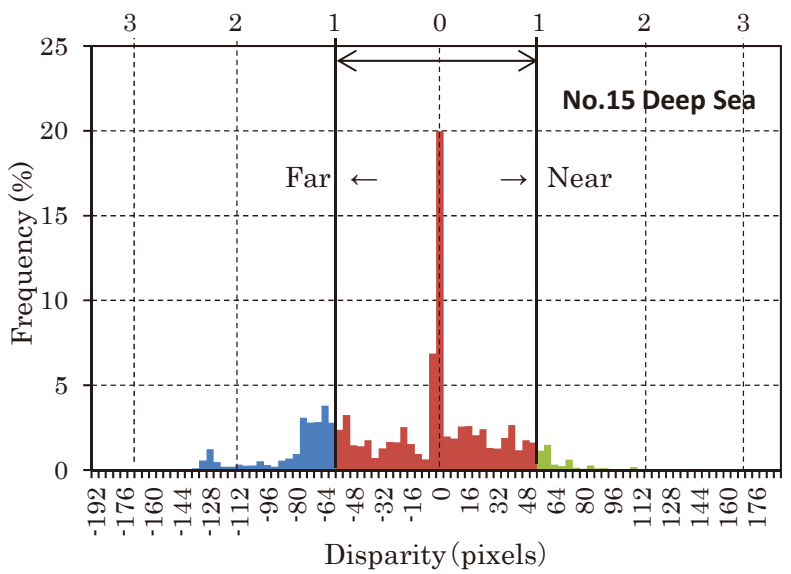

(c) No.15 ディープシー [Deep Sea $]$

図6 特徴的な視差をもつ三つの $3 \mathrm{D}$ コンテンッの飛出と引込の視差 ヒストグラム

Disparity histogram of three 3D movies that have distinctive depth characteristics.

15\%を超える。これらはいわゆる戦闘もので意図的に飛出 の効果を狙ったものと考えられる。

一方，ハリウッド系の実写を主体とする映画は， $1^{\circ}$ 以上 の飛出が生じるフレームの割合は概ね $5 \%$ 以下であった。

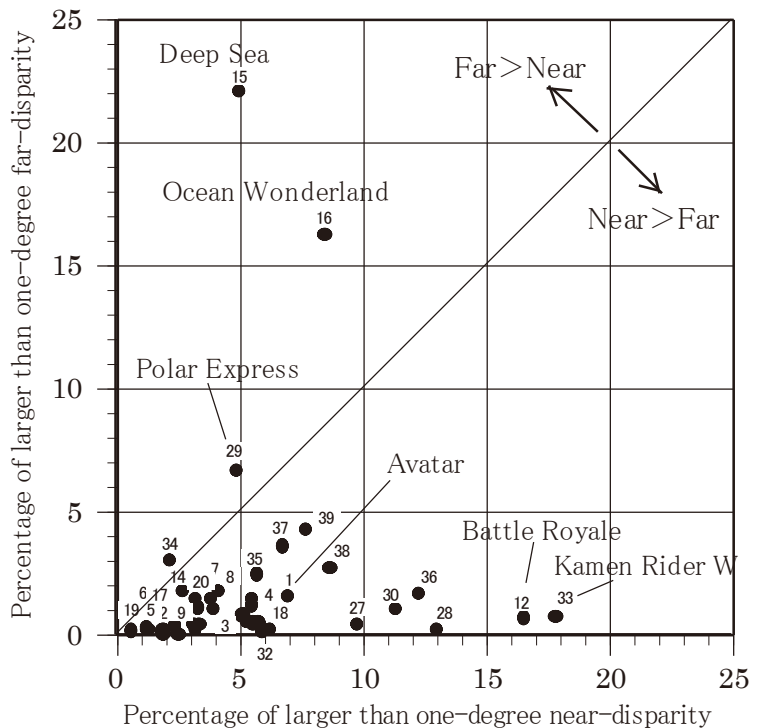

図740種類の $3 \mathrm{D}$ コンテンッにおける視差角 $1^{\circ}$ 以上の飛出と引达の 割合

Percentage of images with greater than $1^{\circ}$ of disparity among the 40 3D movies.

ハリウッド系の実写を主体とする映画の中では「No.1アバ ター」が $1^{\circ}$ 以上の飛出の割合が最も高かったが，それでも 7\%であった。

これらの結果は, 視差角が $1^{\circ}$ 超えるフレームの割合で 3D コンテンツの視差を特徴づけたものであるが，図6に示 したような飛出と引込の視差ヒストグラムの形状から視差 を特徴づけることもできる。図 8 (a) は，「No.16オーシャ ンワンダーランド」の飛出と引达の視差ヒストグラムであ る.図6 (c) に示した「No.15ディープシー」と同様に水中 シーンが多く引込が多い。この二つの視差ヒストグラムの 形状は極めて類似している。また，図8（b）に示した $\lceil\mathrm{No} .33$ 仮面ライダーW」と図 6 (b) の「No.12 バトルロワイ アル」の視差ヒストグラムも類似している.

そこで，ヒストグラム間の類似度を求める際に用いられ るバタチャリア係数 (Bhattacharyya Coefficient)を40コン テンツの視差ヒストグラムのすべての対 $(40 \times 39 / 2=780)$ で求めた. バタチャリア係数は, 式 (1) と（2）に示したよ うにヒストグラムを正規化してからヒストグラムの対応す るビンを掛け合わせて算出する。二つのヒストグラムの類 似度を表すバタチャリア係数は 0 から 1 までの值を取り， 正規化した二つのヒストグラムが完全に一致する場合 1.0 になる。

$$
\begin{aligned}
& L=\sum_{i=1}^{n} \sqrt{P_{i} Q_{i}} \\
& \sum_{i=1}^{n} P_{i}=\sum_{i=1}^{n} Q_{i}=1
\end{aligned}
$$

ここで， $n$ はヒストグラムのビンの数， $P, Q$ は正規化ヒス トグラムである.

先に視差ヒストグラムの類似度の高さを示した図 6 (c) 


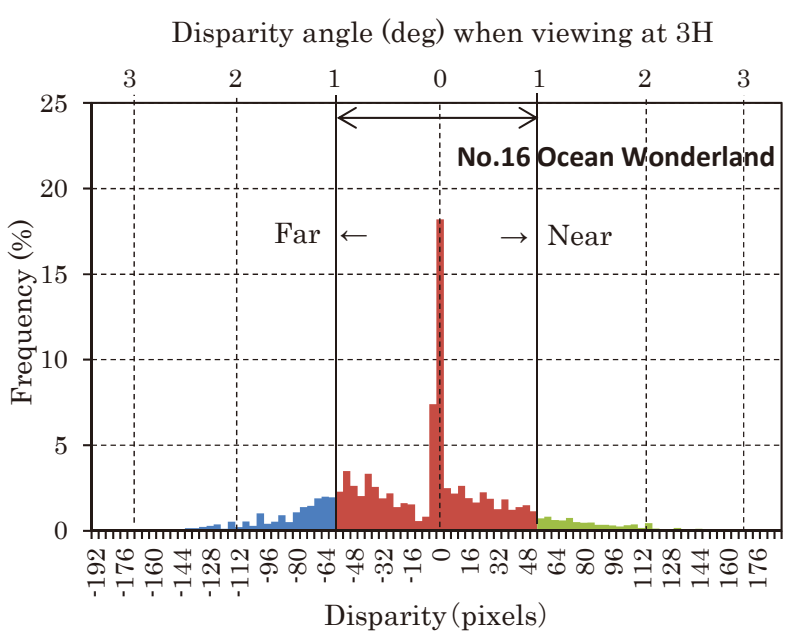

(a) No.16 オーシャンワンダーランド [Ocean Wonderland]

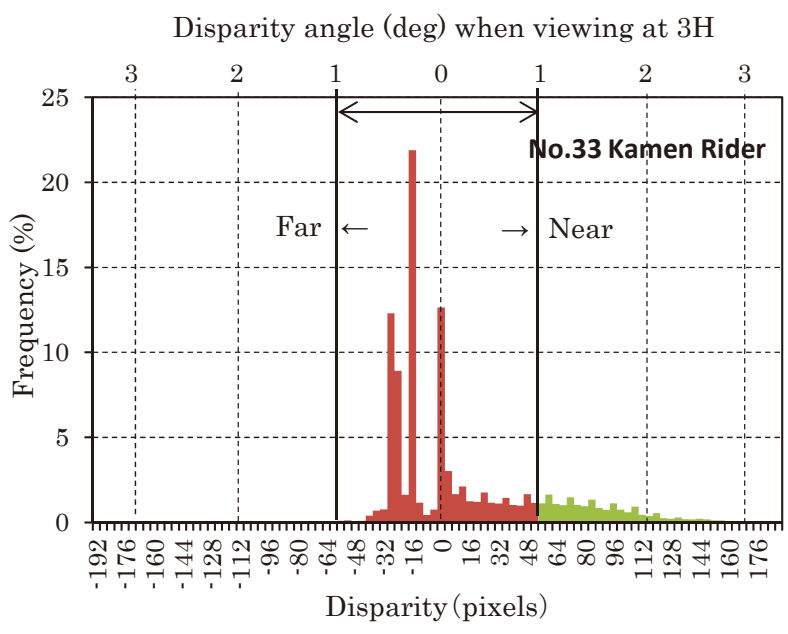

(b) No.33 仮面ライダーW [Kamen Rider W]

図8 飛出と引込の視差ヒストグラム

Disparity histograms of two 3D movies.

「No.15ディープシー」と図8 (a)「No.16オーシャンワンダー ランド」のバタチャリア係数は 0.97 であった。同様に図 6 (b)「No.12 バトルロワイアル」と図8 (b)「No.33仮面ライ ダーW」は，0.81であった.

このバタチャリア係数による類似度を距離尺度に変換し

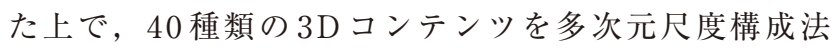
(MDS: Multi Dimensional Scaling)により分類を試みた. ここで距離尺度は, ヘリンガー距離 (Hellinger distance) を用いた。ヘリンガー距離 $\mathrm{H}$ は, バタチャリア係数 Lから 以下のように求められる.

$$
H=\sqrt{1-L}
$$

図 9 が 40 種類の $3 \mathrm{D}$ コンテンツの視差ヒストグラムの類 似度 (ヘリンガー距離) から MDSによって各コンテンツ間 の距離を 2 次元平面上に布置したものである. MDSはIBM SPSS Statistics Ver.20のALSCALを用い，尺度水準を間 隔尺度と指定して計算を実行した。図中の番号は, 表1に 示したコンテンッの番号を表している。図中で近距離に布
置されたコンテンツ同士は視差の付け方が類似していると 言える. 具体的な視差ヒストグラムの特徵が把握できるよ うに，図中にできる限りヒストグラムの形状を示した。例 えば, 図の右下の 15 と 16, ディープシーとオーシャンワ ンダーランドは，すでに述べたように，他の視差ヒストグ ラムと比較して引达が多く, 中心に高いピークがあり分布 の裙野が相対的に広いことが判る。また，これもすでに言 及した 12 バトルロワイアルと 33 仮面ライダーWは，他の コンテンツと比較して, 飛出が多く, 二峰性の分布を成し, 罒の右上に布置されている.

このようにして，視差ヒストグラムの特徴を図の全体に 亘ってみると, 図の横軸は分布の裾野の広がり, 縦軸は分 布の峰の幅を表しているようである.すなわち, 眓の左側 の分布は裾野が狭いのに対して, 右へ行くほど裾野が広 がっている．また，図の上方に行くほど分布の峰が広がり， 多峰性を示す傾向が認められる.これらの結果は, 市販さ れている $3 \mathrm{D}$ 映像の視差の特徵を表しているだけであり， 制作方法や映像内容との関係が推定できるのは先に述べた ごく一部のコンテンツに限られる。ただし, 視差の大きさ が視覚負担の主因であるという前提では，図の左下にある コンテンツの負担が軽く, 図の右上方向に行くほど負担が 大きいコンテンツであるといえる，今後，視覚的な不快感 との関係を明確にすることによって，これらの分析結果の 意義が高まるといえよう。

以上の結果は, 視差の大きさの出現頻度から分析したも のであり, 視差の時間的な変化は捉えられていない. 視差 角が比較的小さい映像であっても奥行き方向の速い動きが あると視覚的不快感や視覚疲労が生じやすいとされている 2) 4). したがって，時系列で視差角の変化を記述する必要 がある. 図 10 は「No.1アバター」の5分間のシーンの飛出, 引込の時間的変化をプロットしたものである．実際に映像 を視聴して確認したが，各シーンの飛出と引込の変化が的 確に表されていた，今後は，このような視差量の時間的な 変化についてもコンテンツの特徵を表現する方法について 検討していく必要がある.

3D 映像の視聴による視覚疲労については, 実際のコンテ ンツを用いて, 本研究で示したような視差の大きさと視差 の時間的な変化の両面の影響を評価していくことによっ て, ディスプレイとコンテンツ双方の改善課題を見出すこ とができると考えられる。

\section{4.むすび}

視聴者の見えに対応した $3 \mathrm{D}$ 映像の飛出, 引込の視差量 の分析方法を提案し, 市販の 40 種類の $3 \mathrm{D}$ コンテンツの視 差を分析した。

まず，ステレオマッチングによりフレームごとに画素単 位で算出した水平方向の視差ヒストグラムのパーセンタイ ルから視聴者が当該フレームで最も飛出ているとする部分 と最も引达んでいるとする部分の視差量を予測する方法に 


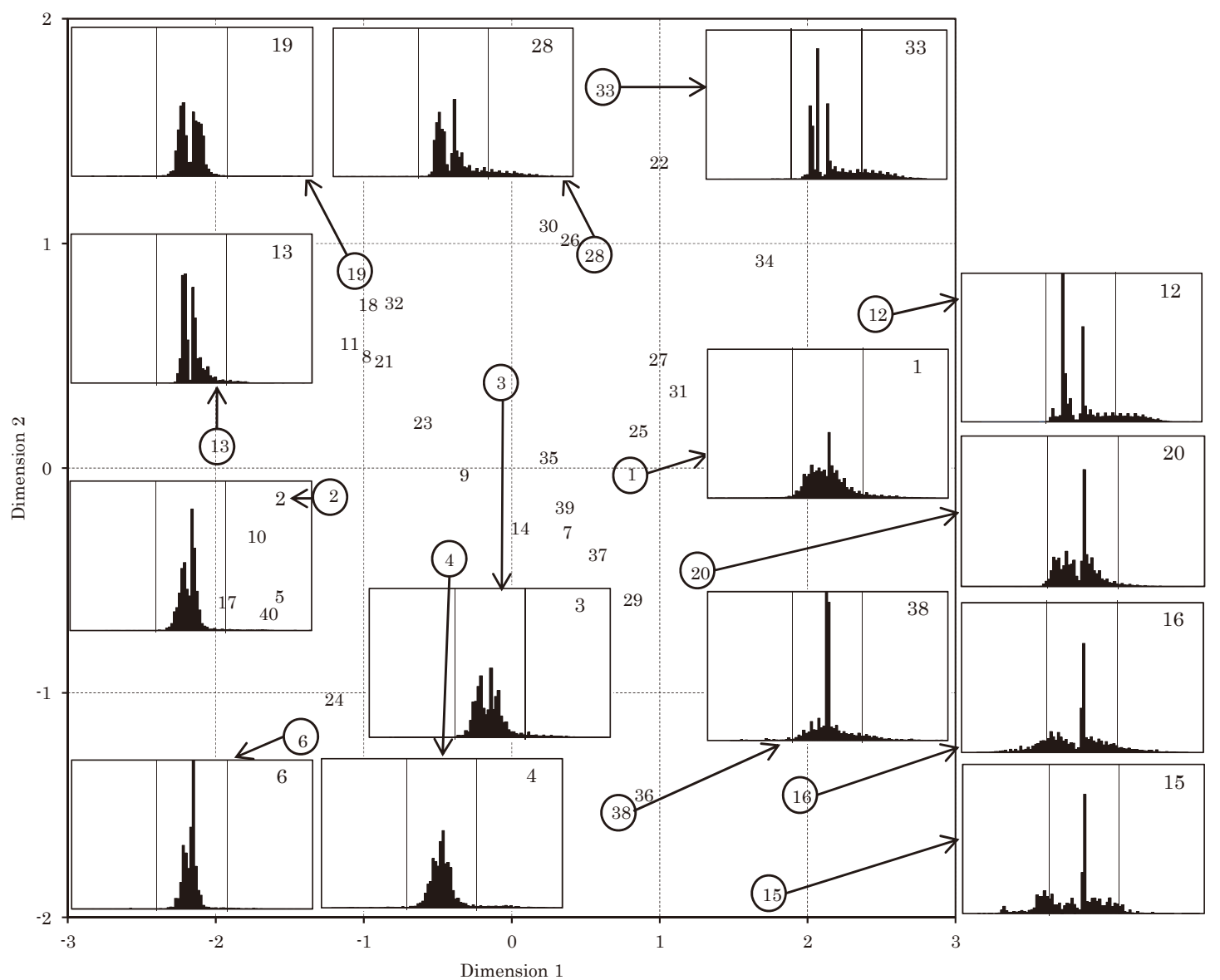

図9 視差ヒストグラムの類似度に基づき多次元尺度構成法を用いてプロットしたマップ. 1〜 40の番号は表1のコンテンッ番号を示す. Similarity matrices of the disparity histograms plotted in a multidimensional scaling ordination. Numbers correspond to those used in Table 1 and indicate the 3D movie.

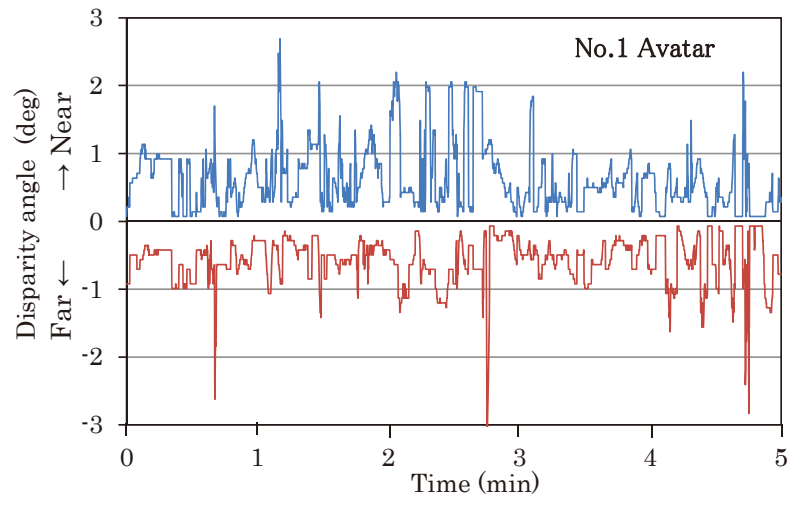

図10 飛出と引込の視差角の時間的変化 (No.1アバタの一部) Disparity changes over time (5 min section of Avatar).

ついて検討した。

そして，視差ヒストグラムの 2.5 パーセンタイルと 97.5 パーセンタイルから, 分析対象とした $8 つ の 3 D$ 映像につい ては, 寄与率 0.9 以上で引込視差と飛出視差が予測できる ことを示した。

その方法をさまざまなジャンルから集めた 40 種類の $3 \mathrm{D}$ コンテンツの視差量の分析に適用し, 以下のような結果を
得た。

(1) 飛出側と引込側の視差角 $1^{\circ}$ を超えるフレームの割合 からコンテンツによって異なる視差の特徵の一側面 を表すことができた。

(2) いずれのコンテンツも視差角 $1^{\circ}$ 超える飛出ないし 引込があるフレームが存在したが，9割のコンテンツ は，飛出側の方が引込側より多かった。

（3）飛出と引込の視差ヒストグラムの類似度に基づく多 次元尺度構成法により，視差量から見たコンテンッ 全体の構造を表すことができた.

(4) 飛出と引込の視差の時間的な変化から奥行き方向の 視差の時系列変化の一例を示すことができた.

本研究で示した視差の分析方法を適用することによっ て，視聴者の見えに対応した視差の大きさや視差の時系列 変化をコンテンツごとに記述することができる．今後は， これらの視差量の特徴と視覚的不快感や視覚疲労との関係 について検討していく必要がある.

最後に分析にあたって協力を得た滝沢大貴さんと松本修 太郎さんに感謝します。 


\section{〔文 献〕}

1) M. Wöpking: "Viewing comfort with stereoscopic pictures: An experimental study on the subjective effects of disparity magnitude and depth of focus", Journal of the SID, 3, 3, pp.101-103 (1995)

2) 矢野澄男, 江本正喜, 三橋哲雄 : “両眼融合立体画像での二つの視覚 疲労要因”, 映情学誌, 57, 9, pp.1187-1193（2003）

3) K. Ukai, P.A. Howarth: "Visual fatigue caused by viewing stereoscopic motion images: Background, theories and observations", Displays, 29, 2, pp.106-116 (2008)

4) M. Lambooij, W. IJsselsteijn, M. Fortuin, I. Heynderickx: "Visual discomfort and visual fatigue of stereoscopic displays: A reviwe", Journal of Imaging Science and Technology, 53, 3, pp.030201_1030201_14(2009)

5）河合隆史, 盛川浩志, 太田啓路, 阿部信明：“3D立体映像表現の基 礎一基本原理から制作技術までー”，オーム社（2010）

6） 3D コンソーシアム（3DC）安全ガイドライン部会：“人に優しい $3 \mathrm{D}$ 普及のための $3 \mathrm{DC}$ 安全ガイドライン”，3D コンソーシアム，2010年 4 月 20 日改訂版 (2010)

7）窪田 悟, 工藤広太郎, 竹本雅憲, 嶋田 淳, 中村芳知：“3D テレ ビの視聴による視覚疲労と視聴者の視機能との関係”, 映情学誌, 67 , 7, pp.J262-J269 (2013)

8) K. Konolige: "Small vision system: hardware and implementation", Robotics Research: the Eighth International Symposium, Japan International Symposium of Robotics Research 1997 (1997)

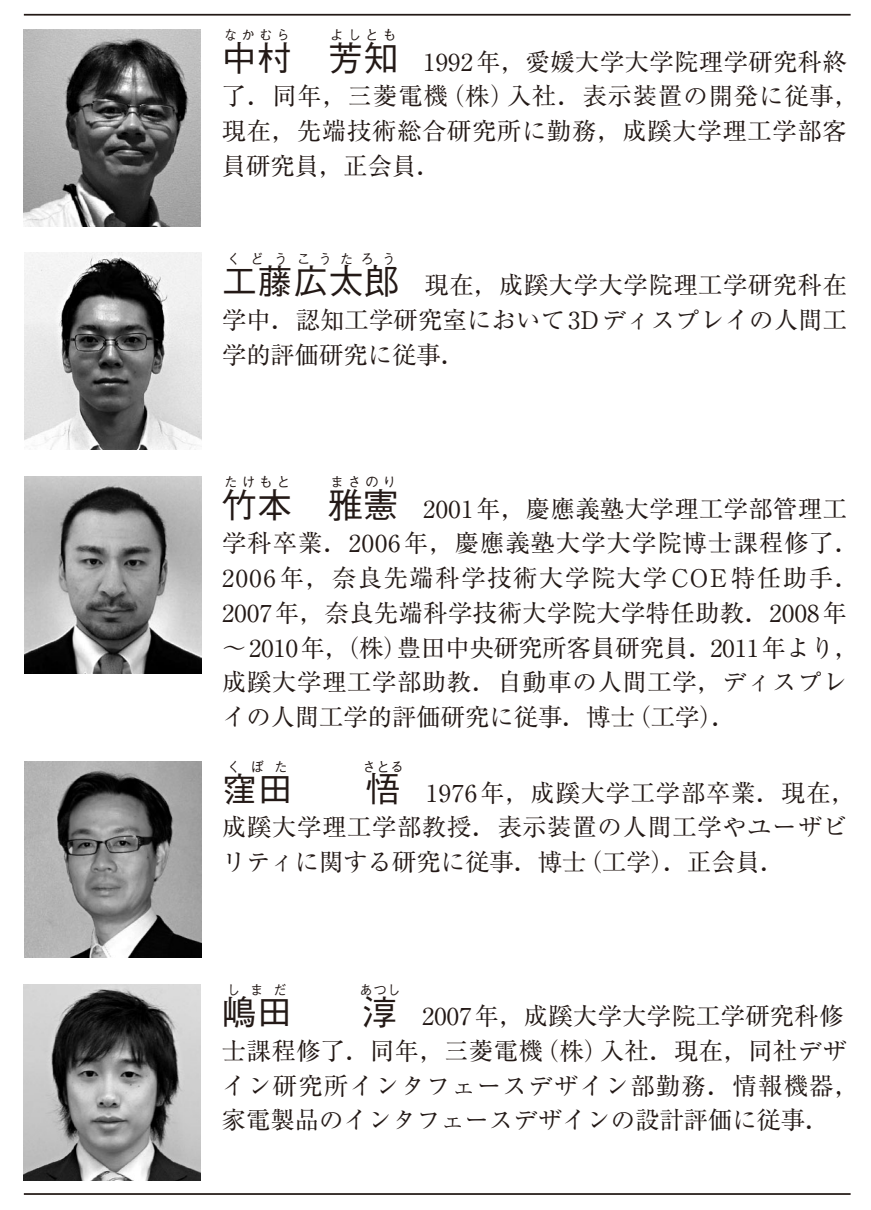

